\title{
A COMPARISON OF SPONGE FAUNA OF EXPOSED AND SHELTERED REEF FLATS IN EASTERN INDONESIA
}

\author{
by \\ ICHSAN AMIR $^{1)}$ \\ ABSTRACT
}

A total of 116 specimens belonging to 61 sponge species were colleted from the reef flat of four different localities in Eastern Indonesia, namely : Maisel, east of Sumba, north' of Sumbawa and $^{\wedge}$ Bahuluang. The sponge species of exposed (Maisel), disturbed (Sumba and Sumbawa) and sheltered (Bahuluang) reef flats are compared using cluster and inverse analysis. The differences in composition of sponge species among those localities are described and discussed.

\section{ABSTRAK}

Sejumlah 116 individu dari 61 jenis sponge didapatkan dari rataan terumbu pada empat lokasi yang berlainan di Indonesia Timui, yaitu : Maisel, Sumba bagian timur, Sumbawa bagian utara dan Bahuluang. Hewan-hewan sponge dari rataan terumbu terbuka (Maisel), rataan temmbu terganggu (Sumba dan Sumbawa), rataan terumbu terlindung (Bahuluang) dibandingkan dengan menggunakan analisa jenis sponge inversi. Perbedaan-perbedaan dalam komposisi jenis sponge antara lokas-lokasi tersebut dipertelakan dan didiskusikan.

\section{INTRODUCTION}

Reef is complicated system, with a high species diversity. Each part of the reef is affected by different regimes of wave action, water currents, and storm surge, or by storm heat of low light intensity. life on the reef has adjusted to resist or to make best use of these influences, thus it appears that distribution of each different species is related to those environmental factors (SHEPPARD, 1983). Studies on reef sponge faunas show that sponges are major inhabitants of the reef environment both in biomass and in species diversity (VAN SOEST, 1984).

The morphology of a sponge is influenced by its environment. According to BERGQUIST (1978) that the shape of sponge can vary considerably within a single species, and the major factor contributing to this variability is the physical environment. Specimens exposed to heavy wave action and storm may be low and encrusting, whereas specimens of the same species growing in sheltered waters (perhaps deeper or in

1) Research and Development Centre for Oceanology-UPI, Jakarta, Indonesia. 


\section{AMIR}

(estuary), may be upright or massive. The texture of sponges, too, can be altered by the environment. Sponges growing in sandy areas are often quite hard, reflecting the accumulation of sand in their tissues. The same species growing in a sandless environment may be quite compressible.

The impact of those factors on shape and texture of sponges could be useful in order to find existing correlation between the environments and the occurrence of sponge taxa.

The aim of this study is as a preliminary study to find out what differences in taxonomic composition between more exposed and sheltered reef flat sponge faunas. To meet this purpose four different reef flat localities were chosen in Eastern Indonesia on account of their different exposure to wave and currents. Emphasis in this preliminary study is on the occurrence of sponge species and descriptive ecology. The sponge faunas of the four localities were compared and classified using quantitative ecological methods. The results are tentatively assumed to be related to environmental differences existing on various reef flat localities.

\section{MATERIALS AND METHODS}

The study area consists of four localities, namely :

1. Maisel Islands, very small islands in the open Banda Sea. The collected samples were randomly taken from the reef flat in the position $5^{\circ} 28^{\prime} \mathrm{S}$. and $127^{\circ} 31^{\prime} \mathrm{E}$., north of Maisel, on the 7th September 1984, by way of snorkeling and hand collecting. According to BAK \& POVEL (1989), analysis of reef compositions (Principle Component Analysis - using shapes and percentage cover of major reef biodata) indicated that it has to be considered an exposed locality.

2. Sumba Island, east of Sumba (Melolo). BAK \& POVEL defined Sumba (Melolo) as a pcysically disturbed locality. The reef flat contained some sediments and was dominated by (green) algae. The collected samples were randomly taken from the reef flat ini the position nearby east of Melolo $9^{\circ} 54^{\prime} \mathrm{S}$. and $120^{\circ} 42^{\prime} \mathrm{E}$, on the 15th of September 1984.

3. Sumbawa Island. The collected samples were randomly taken from the reef flat at the Bay of Sanggar in a position nearby $8^{\circ} 29,5^{\prime} \mathrm{S}$. and $118^{\circ} 15,7^{\prime}$ E. by SCUBA diving \& snorkeling, on the 22nd of September 1984. BAK \& POVEL classify it as a biologically disturbed locality.

4. Bahuluang Island. It is a small island south-west of the Salayar group in the Flores Sea. Most of the reef flat on the east coast of Bahuluang is covered by a seagrass bed with isolated corals. The east coast of this locality is defined as a sheltered locality with the most of water movement coming from the tidal currents passing between Salayar and Bahuluang. The collected samples were randomly taken from 


\section{Sponge Fauna}

the reef flat in position nearby $6^{\circ} 28^{\prime} \mathrm{S}$. and $120^{\circ} 26,5^{\prime} \mathrm{E}$. by snorkeling on the 1 st of October 1984.

The description of the above mentioned localities were cited from BEST and MOLL (1985), BAK and POVEL (1989) and field notes made by VAN SOEST(pers. comm.). The map indicating sampling localities is shown in Figure 1. From those four localities 116 specimens of sponges were collected by Dr. R W. ML VAN SOEST.

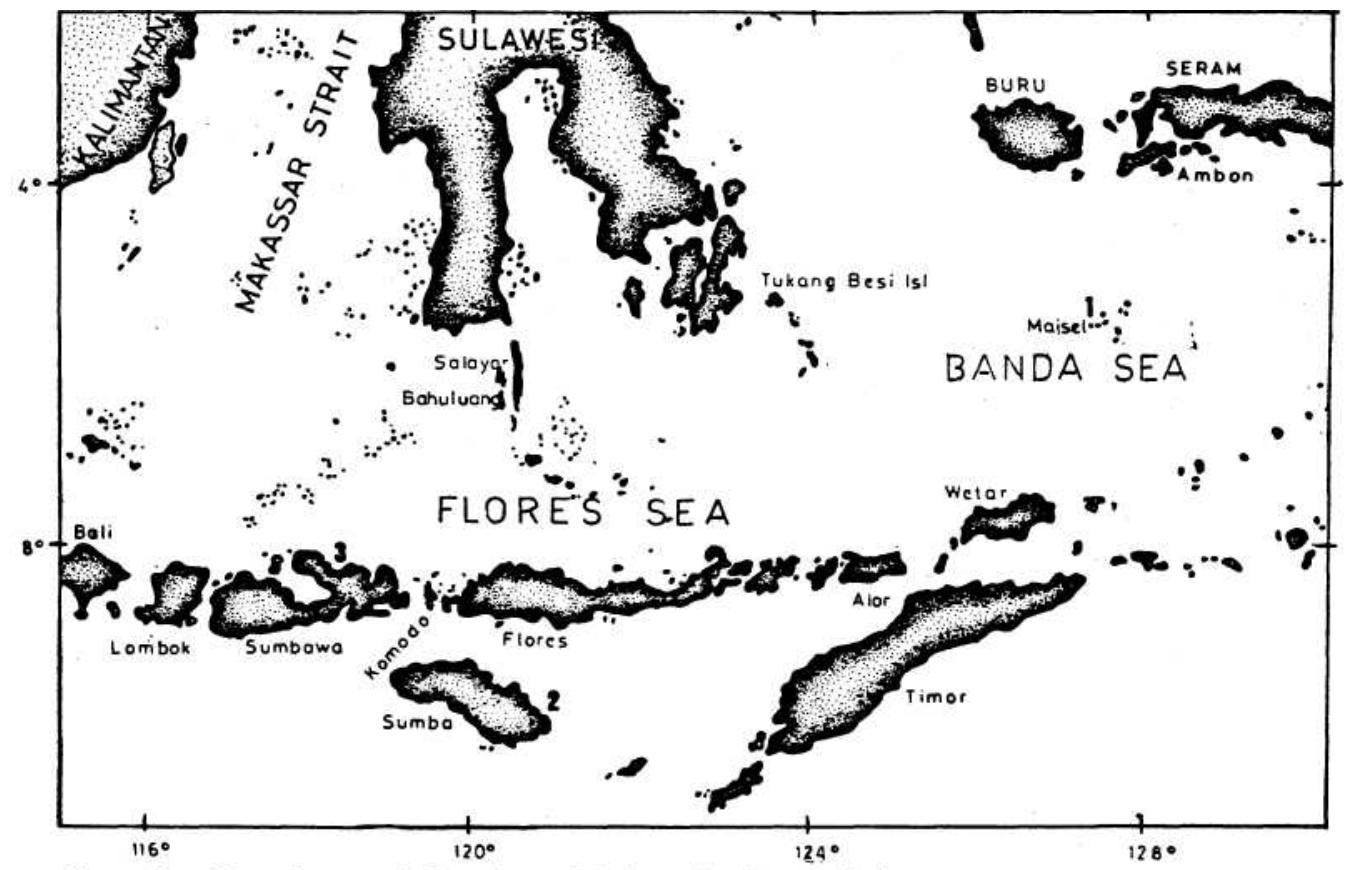

Figure 1. Part of eastern Indonesian archipelago showing studied area.

1) Maisel. 2) Norteast Sumba. 3) Norteast Sumbawa. 4) Bahulang.

In this study, from each specimen was made hand section and boiled preparations. Moreover, literature on the Indo-West Pacific sponges as well as types and other original specimens in the collections of the Institute of the Taxonomic Zoology in Amsterdam were used to lead to proper identifications. The taxonomic description of the sponge specimens will be described in another paper (Amir, in preparation).

Furthermore, the data collected were analysed by means of numerical classification using Cyber 750 Computer at the SARA (University of Amsterdam). The processing of the data was done by using PASCAL programmes. Similarities of the localities considered were compared using the Average Linkage clustering procedure in combination with BRAY-CURTIS dissimilarity index (see KAANDORP, 1986). The results are represented by a dendogram. The analysis of the clusters (the inverse analysis) were analysed using programme "SRTORD" (see KAANDORP, 1986). In this programme, 


\section{AMIR}

the results of the cluster and inverse analysis were combined and represented in one diagram. In order to get an image of the distribution of the quantities of a species over the cluster, two present symbols were used : "*****" and "- - ". The clusters marked with the symbol $" * * * * * "$ are the clusters in which the species are concentrating if the level $70 \%$ and the symbol "- - -" are found additionally if the level is extended to $90 \%$ of the quantities of a species over the cluster.

\section{RESULTS AND DISCUSSION}

Based on identifications of the laboratory work that a total 116 specimens of the four localities consist of 61 sponge species. The results are presented in Tabel 1.

The dendogram of Figure 2, showing that similarities in sponge composition between any two studied localities are less than $50 \%$. There is more similarity between Bahuluang and Sumbawa than between one of these and other localities. And the least similarity is found in a comparison between Maisel and Bahuluang. LEWIS (1964), BERGQUIST (1978) and KAANDORP (1986) wrote that the major factors which may cause the differences between intertidal reef communities are physical factors such as : wave action, currents, topography, substrate, etc. An indication about ecological differences can be found in MOLL (1986) who compared coral community structures in eastern Indonesia, and he found that the most differences in coral compositions can be related to the degree of exposure to water movement.
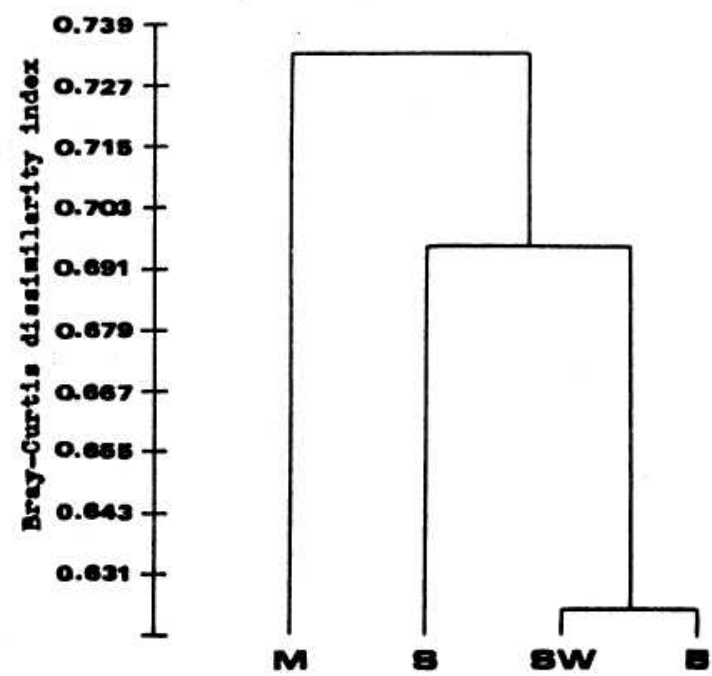

Figure 2. Dendogram of sponge fauna of four localities.

Value indicate dissimilarity $(\mathrm{O}=$ completely similar) as determined by BRAY-CURTIS dissimilarity index. (M: Maisel; S: Sumba; SW: Sumbawa; B. Bahulung). 
Sponge Fauna

Table 1 : Specimens found in the four different localities.

M : Maisel. S: Sumba. SW : Sumbawa. B : Bahuluang.

\begin{tabular}{|c|c|c|c|c|c|}
\hline FAMILY & SPECIES & $\mathbf{M}$ & $\mathbf{S}$ & SW & B \\
\hline Leucettidae & Leucetta microraphis & 0 & 0 & 1 & $\mathbf{0}$ \\
\hline \multirow[t]{2}{*}{ Stelletidae } & Ecionemia acervus & 1 & 0 & 0 & 2 \\
\hline & Stelleta clavosa & 1 & 2 & 2 & 1 \\
\hline Goodiidae & Erylus lendenfeldi & 1 & 0 & 0 & 0 \\
\hline Tetillidae & Cinachyra australiensis & 1 & 0 & 2 & 1 \\
\hline \multirow[t]{3}{*}{ Clionidae } & Cliona sp. aff. viridis & 1 & 0 & 0 & 0 \\
\hline & Cliona sp. 1 & 0 & 0 & 0 & 1 \\
\hline & Cliona sp. 2 & 0 & 0 & 0 & 1 \\
\hline \multirow[t]{3}{*}{ Spirastrellidae } & Spirastrella vagabunda & 1 & 1 & 0 & 2 \\
\hline & Spirastrella solida & 0 & 0 & 0 & 1 \\
\hline & Timea granulata & 0 & 0 & $\theta$ & 1 \\
\hline Tethydae & Tethya robusta & 0 & 1 & 0 & 0 \\
\hline Suberitidae & Terpios sp. aff. fygax & 0 & 1 & 0 & 2 \\
\hline Chondrosidae & Chondrilla australiensis & 0 & 1 & 0 & 0 \\
\hline Euryponidae & Acanthostylotella cornuta & 1 & 0 & 0 & 0 \\
\hline Axinellidae & Pseudaxinella massa & 1 & 0 & 2 & 1 \\
\hline \multirow[t]{5}{*}{ Halichondriidae } & Myrmekioderma granulata & 2 & 0 & 0 & 0 \\
\hline & Amorphinopsis excavans & 0 & 1 & 0 & 0 \\
\hline & Axinyssa variabilis & 0 & 1 & 0 & 0 \\
\hline & Axinyssa aplysinoides & 0 & 0 & 1 & 2 \\
\hline & Ciocalypta heterostyla & 0 & 1 & 0 & 0 \\
\hline Rhabderemiidae & Rhabderemia conulosa & 0 & 0 & 1 & 0 \\
\hline \multirow[t]{5}{*}{ Microcionidae } & Clathria reinwardti & 0 & 0 & 1 & 1 \\
\hline & Clathria eccenttica & 1 & 0 & 0 & 0 \\
\hline & Rhaphidophlus fasciculata & 0 & 0 & 1 & 0 \\
\hline & Rhaphidophlus sp. 1 & 0 & 1 & 0 & 0 \\
\hline & Rhaphidophlus sp. 2 & 0 & 0 & 1 & 0 \\
\hline Myxillidae & Tedania maendriea & 0 & 0 & 1 & 0 \\
\hline \multirow[t]{3}{*}{ Mycalidae } & Mycale lissochela & 0 & 0 & 1 & 0 \\
\hline & Mycale gelatinosa & 0 & 0 & 1 & 0 \\
\hline & Mycale obscura & 0 & 0 & 0 & 3 \\
\hline
\end{tabular}




\begin{tabular}{|c|c|c|c|c|c|}
\hline \multirow[t]{3}{*}{ Desmacididae } & lotrochota baculifera & 1 & 0 & 1 & 1 \\
\hline & Liosina paradoxa & 0 & 0 & 1 & 0 \\
\hline & Coelocarteria singaporense & 0 & 1 & 1 & 1 \\
\hline \multirow[t]{2}{*}{ Petrosidae } & Xestospongia axigua & 1 & 0 & 1 & 0 \\
\hline & Xestospongia sp. aff. carbonaria & 0 & 0 & 1 & 0 \\
\hline \multirow[t]{3}{*}{ Oceanapiidae } & Aka mucosa & 1 & 0 & 0 & 0 \\
\hline & Aka sp. 1 & 2 & 0 & 0 & 0 \\
\hline & Oceanapia sp. 1 & 0 & 1 & 0 & 0 \\
\hline Callyspongiidae & Callyspongia monilata & 0 & 0 & 0 & 1 \\
\hline \multirow[t]{2}{*}{ Niphatidae } & Amphimedon sp & 1 & 0 & 0 & 0 \\
\hline & Gelliodes pumila & 0 & 1 & 1 & 1 \\
\hline \multirow[t]{7}{*}{ Chalinidae } & Haliclona hamata & 0 & 0 & 0 & 1 \\
\hline & Haliclona pigmentifera & 1 & 3 & 0 & 3 \\
\hline & Haliclona violacea & 1 & 0 & 0 & 0 \\
\hline & Haliclona sp. 1 & 3 & 0 & 0 & 0 \\
\hline & Haliclona sp. 2 & 0 & 0 & 0 & 1 \\
\hline & Haliclona cymaeformis & 0 & 1 & 1 & 0 \\
\hline & Dendroxea sp. 1 & 0 & 0 & 0 & 3 \\
\hline \multirow[t]{4}{*}{ Spongiidae } & Spongia irregularis & 1 & 1 & 0 & 0 \\
\hline & Dactylospongia elegans & 0 & 0 & 2 & 0 \\
\hline & Phyllospongia foliascens & 0 & 0 & 1 & 1 \\
\hline & Phyllospongia papyracea & 0 & 0 & 0 & 1 \\
\hline \multirow[t]{3}{*}{ Thorectidae } & Ireinia ramosa & 1 & 1 & 2 & 0 \\
\hline & Hyrtios erectus & 1 & 0 & 1 & 0 \\
\hline & Smenospongia sp. & 1 & 0 & 0 & 0 \\
\hline Aplysillidae & Pleraplysilla australis & 0 & 0 & 0 & 1 \\
\hline \multirow[t]{3}{*}{ Dysideidae } & Dysidea herbacea & 3 & 0 & 0 & 0 \\
\hline & Dysidea arenaria & 0 & 0 & 1 & 0 \\
\hline & Dysidea granulosa & 0 & 0 & 2 & 0 \\
\hline \multirow[t]{2}{*}{ Aplysinellidae } & Druinella purpurea & 0 & 1 & 1 & 1 \\
\hline & TOT A L & 29 & 20 & 32 & 35 \\
\hline
\end{tabular}




\section{Sponge Fauna}

Thus, we may assume that the differences of those sponge compositions could be also related to the degree of exposure to wave and currents. However, geographical factor may be also assumed to be related to the taxonomic composition, since the four localities in this study are relatively spread over long distance among them. Some indication about geographical differences can be found in VAN SOEST (1989) who compared overall sponge faunas of eight different localities in the eastern Indonesia, and he found high dissimilarities.

Therefore, in this case, we may tentatively interprete that the differences of those compositions could be caused by the major factors such as physical (wave stress) and geographical influences.

The sponge compositions in a sheltered reef flat (Bahuluang) are similar to those in a biologically disturbed reef flat (Sumbawa), then, the compositions of these two localities are also similar to those in a physically (oceanic swell and turbidity) disturbed reef flat (Sumba), these may be due to the more similar from a phycisal as well as geographical point of view. For this study, we may consider that the biological factors (such as predation, competition and eutrophication) might have similar impact as physical factors (such as shelter from wave action). Additionally, Moll (1986) wrote that the action of wind and wave or swell may occur only occasionally in the east of Sumba. Therefore, we may assume that the sponge compositions among these three localities may probably have more similar impacts to wave action (such as a sheltered reef flat) than to those in an exposed reef flat (Maisel).

Furthermore, we can interprete that the comparison of sponge faunas between more exposed and sheltered reef flats in this study have high dissimilarity (similarities are less than $50 \%)$.

The processing of the data using the cluster analysis in combination with the inverse analysis yielded several indications as shown in Figure 2. The results are as follows:

- Sponge species expected to occur at all localities (Figure 3A) could be represented by Spongia irregularis, Haliclona pigmentifera, Ircinia ramosa, Hyrtios erectus, Ecionemia acervus, Stelletta clavosa, Pseudaxinella massa, Gnachyra australiensis, Iotrochota baculifera, and Spirastrella vagabunda. Thus, we could interprete that they are common species for that area. These species might be able to resist to the most factors, such as wave action, competition^ ${ }^{\wedge}$ currents, predation, oceanic swell, turbidity, sedimentation or sheltered condition. For example : Ircinia ramosa (Figure 4A). The shape of this species is ramose, flattened branches, however it can withstand exposed environments. This might be caused by its consistency, which is toughly, spongy and rubbery. Likewise, it is possible that its shape may cause it to survive in spatial competition. Iotrochota baculifera, Gnachyra australiensis, Spirastrella vagabunda, Xestospongia exigua, are also very common to all localities. BERGQUIST \& TIZARD (1967) noted thai they are also widespread species in the Indonesia-Pacific region. Common species have no preference for a particular biotope. We can conclude that a major ecological parameter such as exposure to 


\section{AMIR}

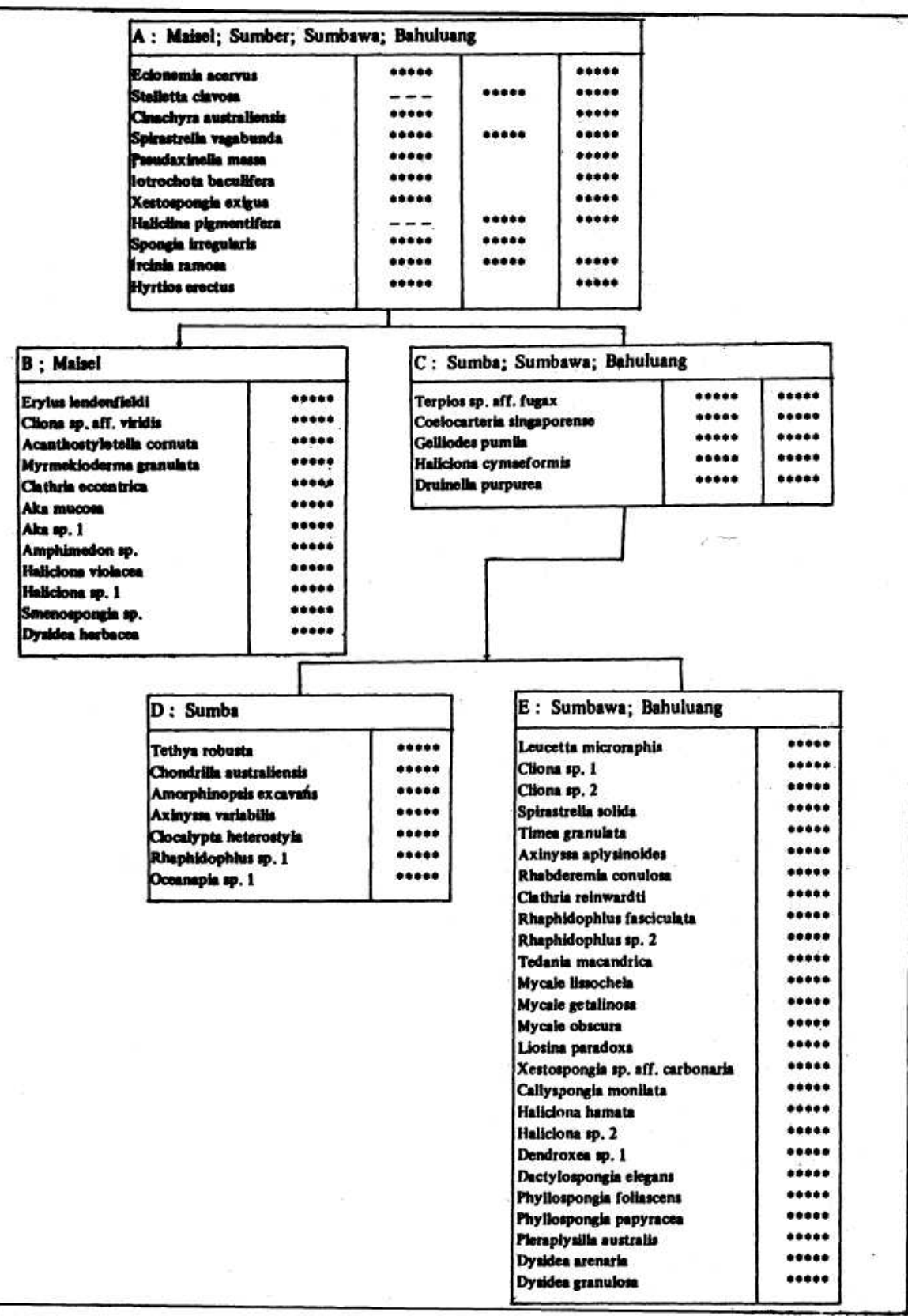

Figure 3. The combination of the cluster and the inverse analysis.

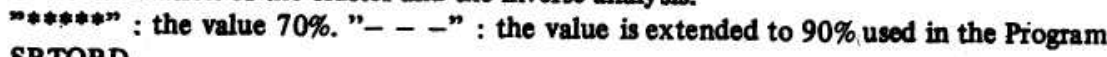
SRTORD. 
Sponge Fauna

wave and currents do not seem to influence the distribution of some of the most common species. In this group, Spongia irregularis is not representative for common species but is incorporated in it because it is the "best fitting" cluster.

- The group prefering to more exposed locality (Figure 3B) may be characterized by sponge species, Le., Amphimedon sp., Haliclona violacea, (Figure 4B) Haliclona sp.l, Aka mucosa, Aka sp.1, Smenospongia sp., Dysidea herbacea, Erylus lendenfeldi, Cliona sp. aff. viridis, Clathria eccentrica, Acanthostylotella cormuta,and Myrmek ioderma granulate Signifcantly, most of them tend to have low or more encrusting shapes. BERGQUIST \& TEZARD (1967) wrote that encrusting sponges will occur in mud-free intertidal areas. Those sponges are favoured in this area, because of strong water currents which serve for food gathering, tissue oxygenation, and other suitable necessities.

- The group which prefers sedimented environments (Figure 3C) may be dominated by the sponge species, Gelliodez pumila, Haliclona cymaeformis, Druinella purpurea, Terpios sp. aff. fugax, Coelocarteria singaporense. These sponge species are found on reef flats of Sumba, Sumbawa and Maisel. They are characterized by their body parts anchored or burrowed in the sediment, sticking out fistular inhalant and exhalant projections and containing sand grains or foreign debris in their tissues. These characters enable them to survive in sandy and muddy environments. For example : the oscular projections of Coelocarteria singaporense (Figure 4C) protrude from the mud.

- The group which prefers oceanic swell or turbidity (Figure 3D) may be characterized by the sponge species, Oceanapia sp.l. Chondrilla australiensis, Tethya robusta, Rhaphidophlus sp.l rGocalypta heterostyla, Amorphinopsis excavans, and Axinyssa variabilis. These sponge species are found on the reef flat of Sumba. They can be characterized by their consistency and shape. For example : Chondrilla australiensis has rubbery-smooth and rounded characters. Tethya robusta (Figure 4D) has hard, rubbery and spherical characters. Rhaphidophlus, sp.l, Amorphinopsis excavans and Axinyssa variabilis are encrusting and stiff.

- The group which prefer to sheltered locality (Figure 3E) are represented by 26 species, e.g. Haliclona hamata, Callyspongia monilata, Liosina paradoxa, Spirastrella solida, Gathria reinwardti (Figure4E), Gathria fasciculata. These sponge are found on reef flats of Sumbawa and Bahuluang. They are characterized by tending to have slightly more upright shapes than the sponges in an exposed locality.

All those observations are conjecture. To ascertain the correlation between environmental pressure and morphological changes of the sponges need detailed research. For instance, the wave action can be assessed by using dynamometers (JONES \& DEMETROPOULOS, 1968), or by measuring the erosion of gypsum blocks (MUUS 1968). 


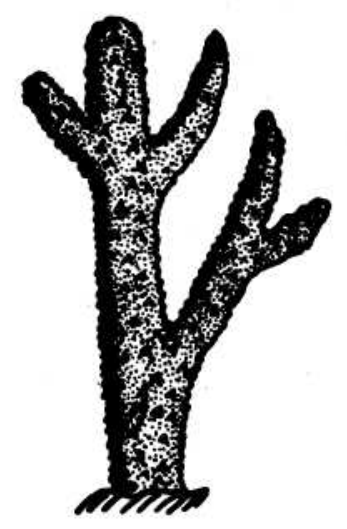

A) Ircinia ramosa (Common species)

C) Coelocarteria singaporense (Prefer sedimented environment)

E) Clathria reinwardti (Prefer sheltered environment)

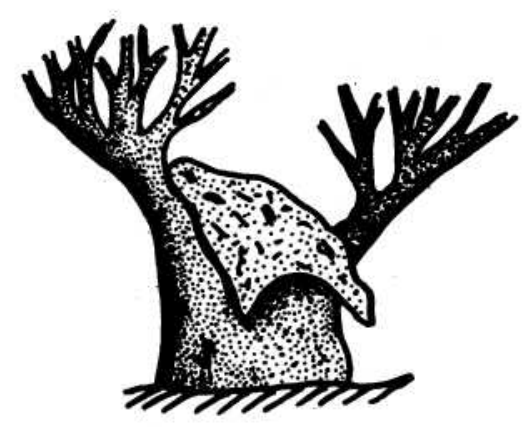

B) Haliclona violacea

(Encrusting-Prefer exposed environment)

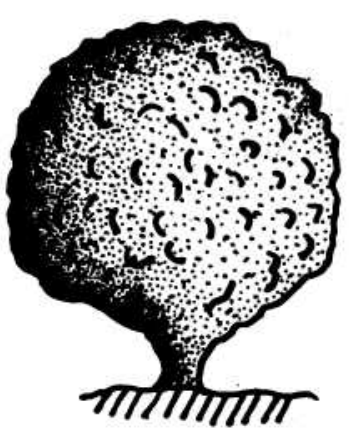

D) Tethya robusta (Prefer oceanic swell/turbidity)

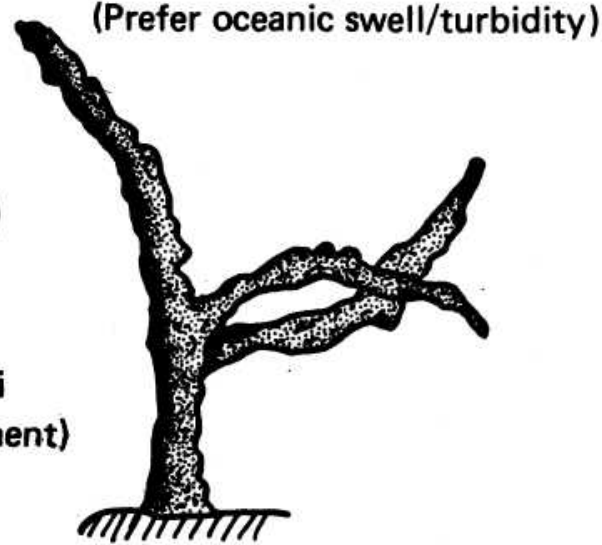

Figure 4. (A-E) : Sketch drawings of representative sponge species of each environment as grouped by the cluster and the inverse analysis. 


\section{Sponge Fauna}

By random sampling on the reef flat conducted once in each locality by hand sorting or snorkeling, it is impossible to avoid sampling bias. Factors such as sampling duration, sampling space, density of the sponge species, and other ecological factors, could influence the sampling data. Therefore, the results must be considered tentative. Consequently, the interpretation could very well be that differences between sponge compositions of the sampled reef flats are due to physical and geographical factors. Of course, it must be admitted that further research is still needed to be done. Several surveys over a longer period of time can show where, how, and at what pace, changes are taking place. These are useful since several species of sponges are known to have use and economic importances. For example ; As biological pollution indicator, natural bath sponges, new pharmacological products and bioactive substances (anti-inflammatory and natural anti fouling). Additionally, only through joint efforts of teams of scientists, we can hope to have a good grip of the living sponges of Indonesia.

\section{REFERENCES}

BAK, R.P.M \& G.D.E POVEL, 1989. Ecological variables, including physiognomicstructural and classification of Indonesian coral reefs. Neth. J. Sea Res. 23 (2) :

215-222.

BERGQUIST, P.R. \& GA. TIZARD, 1967. Sponge industry. In : F.E. Firth (Ed). Encyclopedia for Marine Resources : 665-670.

BERGQUIST, P.R., 1978. Sponges. Hutchinson, London : 268 pp.

BEST, M.B. \& H. MOLL, 1985. Investigations of recent and fossil coral reefs in eastern Indonesia (Snellius - II Expedition). A preliminary report. Proc. Fifth Int. Coral Reef Congress, Tahiti, 6:311-316.

JONES, E.W. \& A. DEMETROPOULOS, 1968. Exposure to wave action, measurements of an important ecological parameter on rocky shores on Anglesey. \%. Exp. Mar.Biol.EcoL, 2:46-63.

KAANDORP, J.A., 1986. Rocky substrate communities of the infralittoral fringe ot the Boulonnais Coast, N.W. France : A quantitative survey. Mar.Biol 92 : 255-265.

LEWIS, J.R., 1964. The ecology of rocky shores. The English University Press Ltd. London: $323 \mathrm{pp}$.

MOLL, H., 1986. The coral community structure on the reef visited during the Snellius II Expedition in Eastern Indonesia. Deel 60, no. 1,1SSN 0024-0672, : 1-25.

MUUS, BJ., 1968. A field method for measuring "Exposure" by means of plaster balls. A preliminary account. Sarsia 34: 61-68. 
I. AMIR

SHEPPARD, C.R.C., 1983. A natural history of the coral reef. Blandford Press. $31-32$.

SOEST, R.W.M. van, 1984. Marine sponges from Curacao and other Caribbean localities. Part III. Pbecilosclerida. Stud. Fauna Cucarao Caribb.M 56 (199): 1-167.

SOEST, R.W.M. van, 1989. The Indonesian sponge fauna: A status report. Neth, J. Sea Res. 23(2): 223-230. 